NASA/TM-2003-212395

\title{
Mixed-Phase Icing Simulation and Testing at the Cox Icing Wind Tunnel
}

Kamel Al-Khalil and Eddie Irani

Cox \& Company, Inc., New York, New York

Dean Miller

Glenn Research Center, Cleveland, Ohio 
Since its founding, NASA has been dedicated to the advancement of aeronautics and space science. The NASA Scientific and Technical Information (STI) Program Office plays a key part in helping NASA maintain this important role.

The NASA STI Program Office is operated by Langley Research Center, the Lead Center for NASA's scientific and technical information. The NASA STI Program Office provides access to the NASA STI Database, the largest collection of aeronautical and space science STI in the world. The Program Office is also NASA's institutional mechanism for disseminating the results of its research and development activities. These results are published by NASA in the NASA STI Report Series, which includes the following report types:

- $\quad$ TECHNICAL PUBLICATION. Reports of completed research or a major significant phase of research that present the results of NASA programs and include extensive data or theoretical analysis. Includes compilations of significant scientific and technical data and information deemed to be of continuing reference value. NASA's counterpart of peerreviewed formal professional papers but has less stringent limitations on manuscript length and extent of graphic presentations.

- TECHNICAL MEMORANDUM. Scientific and technical findings that are preliminary or of specialized interest, e.g., quick release reports, working papers, and bibliographies that contain minimal annotation. Does not contain extensive analysis.

- CONTRACTOR REPORT. Scientific and technical findings by NASA-sponsored contractors and grantees.
- CONFERENCE PUBLICATION. Collected papers from scientific and technical conferences, symposia, seminars, or other meetings sponsored or cosponsored by NASA.

- SPECIAL PUBLICATION. Scientific, technical, or historical information from NASA programs, projects, and missions, often concerned with subjects having substantial public interest.

- TECHNICAL TRANSLATION. Englishlanguage translations of foreign scientific and technical material pertinent to NASA's mission.

Specialized services that complement the STI Program Office's diverse offerings include creating custom thesauri, building customized databases, organizing and publishing research results ... even providing videos.

For more information about the NASA STI Program Office, see the following:

- Access the NASA STI Program Home Page at http://www.sti.nasa.gov

- E-mail your question via the Internet to help@sti.nasa.gov

- Fax your question to the NASA Access Help Desk at 301-621-0134

- Telephone the NASA Access Help Desk at 301-621-0390

- Write to:

NASA Access Help Desk

NASA Center for AeroSpace Information 7121 Standard Drive

Hanover, MD 21076 
NASA/TM-2003-212395

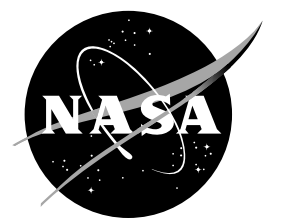

\section{Mixed-Phase Icing Simulation and Testing at the Cox Icing Wind Tunnel}

Kamel Al-Khalil and Eddie Irani

Cox \& Company, Inc., New York, New York

Dean Miller

Glenn Research Center, Cleveland, Ohio

Prepared for the

41st Aerospace Sciences Meeting and Exhibit

sponsored by the American Institute of Aeronautics and Astronautics

Reno, Nevada, January 6-9, 2003

National Aeronautics and

Space Administration

Glenn Research Center 


\section{Acknowledgments}

This program was sponsored by the FAA through a contract to Wichita State University. The support of these two organizations is well appreciated. Participation of the NASA Glenn Research Center in this program provided valuable imaging techniques and recorded visualization.

The Propulsion and Power Program at

NASA Glenn Research Center sponsored this work.

Available from

NASA Center for Aerospace Information 7121 Standard Drive

Hanover, MD 21076
National Technical Information Service 5285 Port Royal Road Springfield, VA 22100

Available electronically at http:/ /gltrs.grc.nasa.gov 


\title{
MIXED PHASE ICING SIMULATION AND TESTING AT THE COX ICING WIND TUNNEL
}

\author{
Kamel Al-Khali1* and Eddie Irani ${ }^{\dagger}$ \\ Cox \& Company, Inc. \\ New York, New York 10014 \\ Dean Miller: \\ National Aeronautics and Space Administration \\ Glenn Research Center \\ Cleveland, Ohio 44135
}

\begin{abstract}
A new capability was developed for indoor simulation of snow and mixed-phase icing conditions. This capability is useful for year-round testing in the Cox closed-loop Icing Wind Tunnel. Certification of aircraft for flight into these types of icing conditions is only required by the JAA in Europe. In an effort to harmonize certification requirements, the FAA in the US sponsored a preliminary program to study the effects of mixed-phase and fully glaciated icing conditions on the performance requirements of thermal ice protection systems. This paper describes the test program and the associated results.
\end{abstract}

\section{$1.0 \quad$ INTRODUCTION}

There are requirements and advisory materials under Joint Airworthiness Requirements (JAR) in Europe that must be satisfied prior to flight into mixed icing and snow conditions [1]. To achieve certification for flight into these conditions, aircraft must demonstrate compliance with those requirements. In the USA, the Federal Aviation Administration (FAA) has issued no such requirements to date other than those restricted to falling and blowing snow with no mention of airspeed [2].

In recent years, several flight programs were conducted in order to re-characterize the atmosphere at different locations around the globe. Most of these programs were geared towards Supercooled Large Droplets (SLD). Among these programs are the NASA Glenn Research Center icing research flights throughout the Great Lakes region, the Canadian Freezing Drizzle Experiment (CFDE) and the Alliance Icing Research Study (AIRS). References [3] through [10] include discussions on those programs. SLD icing conditions are believed to have been a factor in the 1994 fatal crash of an ATR-72 commuter aircraft.

There is evidence from those flight research programs that mixed phase icing conditions can be encountered relatively frequently. In mixed icing conditions, ice crystals and supercooled water droplets coexists.

\footnotetext{
*Manager, LIRL Icing Wind Tunnel, Senior Member AIAA

$\dagger$ Aerospace Research Engineer, Member AIAA

†Icing Research Engineer, Member AIAA
}

Since the ATR-72 accident, the FAA and the JAA have been working on joint programs in order harmonize the certification requirements. The FAA issued a document detailing its in-flight aircraft icing plan, the purpose of which is to increase flight safety [11]. Among the list of tasks is Task 13. Here, the objective is to characterize SLD aloft and assess mixed phase conditions in the atmospheric flight environment. Specifically, Task $13 \mathrm{C}$ states that "The FAA will conduct a study to determine the magnitude of the safety threat that is posed by mixed phase conditions."

Consequently, the FAA sponsored a specialists' workshop on mixed-phase and glaciated icing conditions in Dec 1998. Several presentations were given on the topic as indicated by References [12] and [13]. The experience of authors and experts in the field is that both snow and mixed icing conditions could constitute flight hazards beyond those recognized formally. Insidious accumulations of ice and packed snow in engine inlets and at various locations on the airplane can occur. As already mentioned, the JAA recognizes the hazardous nature of mixed phase and snow conditions and requires testing for engines and air data probes and instrumentation.

The effect of these conditions on heated or unheated lifting surfaces has not been systematically evaluated and documented. In order to address this issue, the FAA sponsored a program to investigate the impact of mixed phase and snow conditions on thermal ice protection systems. An exploratory test was conducted in the Cox \& Company Icing Wind Tunnel (IWT) in July 2002. This was a collaborative effort between the FAA, Wichita State University, Cox \& Company, and NASA Glenn Research Center. 


\subsection{OBJECTIVES AND APPROACH}

Cox developed a new capability in its IWT (Figure 1) to simulate mixed phase and glaciated icing conditions. The development program was carried out through NASA Glenn SBIR Phase-I and Phase-Il awards. This capability was necessary to conduct the current program.

The primary objective of this experimental program was to study the effect of mixed phase and glaciated icing conditions on the performance of thermal ice protection systems. The secondary objective was to study the physics of ice particle behavior on airfoil leading edge surfaces (impact, bouncing, sticking, melting, etc.). A team of engineers from NASA Glenn Research Center carried out the visualization effort using state-of-theart imaging tools and techniques.

A heated and instrumented airfoil model was used in the studies. The heated section consisted of multiple zones that were individually controlled as described later. The model was previously developed for the NASA Code Validation Test Program that was conducted in the NASA IRT as described in References [14], [15] and [16]. The original airfoil model was trimmed from $6 \mathrm{ft}$ to $4 \mathrm{ft}$ span in order to fit in Test Section-2 of the Cox IWT. This test section was chosen to allow atomized particles from the Snow Gun, described later, to nearly fully freeze prior to impact on the model leading edge.

Testing was conducted with the model heaters OFF and ON. The objective of keeping the heaters OFF was to explore and document the icing physics on the surface, including ice particles impacting the surface, bouncing off, partially sticking, melting, etc. In the heater ON case the objective was to document the changes in the icing physics and to determine the power required to maintain the surface at a certain preset temperature.

There are two anti-icing modes of operation of a thermal Ice Protection System (IPS): evaporative and running-wet. In the evaporative mode, the surface is heated sufficiently to evaporate the impinging ice/water particles and prevent runback beyond the heated zone. This requires a surface temperature near to or in excess of $120^{\circ} \mathrm{F}$. In the running-wet mode, the surface is heated to prevent the impinging ice/water particles from freezing within the heated zone. This requires a surface temperature above $32^{\circ} \mathrm{F}$, in practice between 40 and $50^{\circ} \mathrm{F}$.

In order to quantify the effects of ice/water content in the cloud on thermal IPS power requirements, many of the tests were conducted at the same Total Water Content (TWC). The ratio of ice water content to supercooled liquid water content was varied between $0 \%, 50 \%$, and $100 \%$. The IPS operation in the two different modes was conducted at the following temperatures:

\section{Evaporative Anti-icing: surface near $150^{\circ} \mathrm{F}$ \\ Running-Wet power: $\quad$ surface near $50^{\circ} \mathrm{F}$}

The surface temperature in the evaporative mode was higher than the normally used, $120^{\circ} \mathrm{F}$. This was a result of the low air speed which gives a low evaporation rate, and also because water near the stagnation has a greater tendency to bead up at low speed and then run back, producing a frozen ridge beyond the heated zone.

In both heated modes, the power distribution and total power was determined through a closed-loop control system. In the unheated cases, the surface physics and erosion effects of the incoming particles on the ice structure were studied and documented.

\subsection{ICING CLOUD SIMULATION}

The simulation of the different icing clouds was made possible by using a combination of ice and/or supercooled water. The latter was produced using the common spray bar method where filtered and de-ionized water was atomized using compressed heated air. The ice particles were produced using two different methods:

\section{Snow gun:}

Water was atomized through a nozzle using cold compressed air as shown in Figure 2. The cooling of the atomized water droplets produced near spherical ice particles.

Ice Shaver:

Water was frozen in large ice blocks. Subsequently, these blocks were fed at a determined rate through a mechanical shaver that consisted of multiple rotating blades. The shaved ice was then introduced into the freestream via a blower. The ice particles produced using this technique are usually irregular in shape and larger than those produced using the snow gun. Also, the particles are fully frozen as they are produced. Those generated using the snow gun required some residency time in the freestream in order to freeze prior to impacting the test model.

Since differences in particle size and shape can affect impact characteristics, it was desired to 
document particle features. An OAP 2D-Grey laser probe was used to characterize details of ice particles from the snow gun and the ice shaver. The instrument was installed at the same location as the test model prior to the test program. Ice particle images from the snow gun and the ice shaver are shown in Figure 3. Sample results of particle size distribution are shown in Figures 4 and 5 for the snow gun and ice shaver, respectively. Corresponding Mean Volume Diameters (MVD's) were approximately 150 and 185 microns, respectively. In general, ice shaver particle MVD was near or above 200 microns.

The Ice Water Content (IWC) using the snow or the ice shaver was calibrated prior to testing. This was accomplished using the Nevzorov TWC instrument, which consists of two sensors: (1) a LWC sensor, and (2) a TWC sensor. The IWC is computed from the difference between the TWC and the LWC. Generally, the IWC is slightly under-estimated since the LWC sensor has some thermal response from ice particles, which are assumed to bounce off that sensor. Ice particles are assumed to be collected, along with water particles, on the TWC sensor. This does not account for few ice particles bouncing off the TWC sensor, especially in the fully glaciated conditions. Correspondingly, the IWC might be slightly underestimated. The overall accuracy of the Nevzorov probe is acceptable and meets the purpose of this test program.

The cloud simulations were as follows:

\section{Supercooled:}

Tunnel Spray Bars: NASA type nozzles (MOD-1)

\section{Glaciated:}

Snow Gun: Air assisted atomization and freeze-out of water particles

Ice Shaver: Mechanically shaved frozen ice blocks and dispersed in the freestream

Mixed:

\section{Supercooled + Ice Shaver Supercooled + Snow Gun}

\subsection{TUNNEL TEST SETUP}

The IWT shown in Figure 1 can simulate airspeeds in excess of $200 \mathrm{mph}$ at temperatures below $-22^{\circ} \mathrm{F}$ $\left(-30^{\circ} \mathrm{C}\right)$ in its upstream Test Section-1. This section measures 28 inches wide by 46 inches high. The tunnel has a diffuser expanding linearly between this test section and the larger (48"x48") Test Section-2 downstream. All tests were conducted in Test Section-2 where the speed is limited to $120 \mathrm{mph}$. This section was chosen to insure that all ice particles produced using the snow gun were fully frozen. The goal was to obtain additional information from effect of ice particle size and shape using the two different simulation methods.

The airfoil was mounted horizontally in Test Section-2 as shown in Figure 6. All tests were conducted at a single, zero degree angle of attack due to the extent of the tasks to be accomplished within the limited time period. A detailed description of the $3 \mathrm{ft}$ chord by $4 \mathrm{ft}$ span NASA0012 heated airfoil model is provided in Reference [14]. It consisted of 14 individually powered and controlled heater zones. The layout and numbering of the heaters is shown in Figure 6. Seven heaters were duplicated spanwise for redundancy. Additionally, due to the airfoil symmetry and zero degree flow angle of attack, top and bottom redundancy resulted.

The model was fitted with several sensors. Only those that measured the surface temperature near the mid-span were used to acquire data and control the heater power. These were located at $+/-4.5$ inches on either side of the mid-span, centered within each heater width.

The video imaging setup is shown in Figure 7. Three cameras were used to image the leading edge of the test article:

1) A High Definition (HD) video Camera and Recorder were used to capture close-up details of ice particle impact in high resolution

2) A high speed close-up camera to allow slow motion analysis of impact (Phantom V Highframe rate)

3) A mini digital video camera with a wide field of view to provide context for the other two cameras

\subsection{DATA ACQUISITION AND CONTROL}

The Cox Thermal Test Management System (TTMS) was used to power the 14 heated zones and record the data. The TTMS is a computer based test management and data acquisition system. Power was regulated to each particular zone to maintain the specified constant surface temperature for each of the two anti-icing modes of operation (evaporative and running-wet).

In most cases, the TTMS modulated the power below $100 \%$ duty cycle to maintain the surface at $50^{\circ} \mathrm{F}$ in the running-wet modes. However, the hilite heaters (\#4 and \#11) were running at full power in 
evaporative cases as well as in several running-wet cases. The corresponding surface temperature was lower than the preset values, but higher than the freezing temperature. Specific details are discussed in the thermal results section.

\subsection{ICING TUNNEL TESTS}

Testing was conducted at various environmental conditions. Table 1 lists the icing test conditions to be explored. Generally, a mid-range ambient temperature $\left(12^{\circ} \mathrm{F}\right.$ - glaze) and a cold ambient condition $\left(0^{\circ} \mathrm{F}\right.$ - rime) were considered. All tests were run at $120 \mathrm{mph}$ and zero degree angle of attack. Generally, the TWC was near $0.7 \mathrm{~g} / \mathrm{m}^{3}$. Other variations were also explored. The list of icing runs and associated icing conditions from Table 1 are shown in Table 2. This table also indicates the IPS heater mode of operation in each run. The duration of the icing conditions in all the runs was 10 minutes or until stable results were obtained.

\subsection{IMAGING AND VISUAL RESULTS}

A detailed analysis of the visualization data has not been performed yet. However, a few general observations about the data are possible.

Bouncing of ice particles was observed in all runs, with a heated or unheated surface, and with or without a supercooled liquid water spray. With the current visualization and imaging instruments, it is not yet possible to quantify the amount of particles that bounce off the surface. Figure 20, located at the end of this document, illustrates these effects as captured during Run 37 (Condition 10).

In the unheated tests in glaciated conditions, only a layer of frost was visible on the surface with no further accumulation as time progressed. This layer is thought to be the residual of ice particles impacting the surface. This was observed for both the ice shaver and the snow gun. In mixed phase unheated conditions, the phenomenon of erosion was observed on the accreted ice. The effects were temperature dependent.

Figure 8 illustrates the effect of erosion on accreted ice in mixed rime icing conditions. These correspond to Runs 19 and 20. Based on the known conditions and collection efficiency of the supercooled water droplets, it is apparent that the ice shapes were a result of the supercooled water droplets in the mixed cloud. The existence of the ice particles in the mix did not seem to significantly affect the amount of accreted ice. The only noticeable effect of the ice particles was the erosion of the feather-like ice growths close to the impingements limits. Compared to near the stagnation region, this region has low collection efficiency and high local tangential speeds that may cause increased erosion of the accretions. The rime accretions tended to have a smoother appearance in the mixed rime conditions due to the "sand-blasting" effects of the particles.

In mixed glaze ice conditions erosion effects are clearly more significant. To illustrate these effects two cases were conducted at $22^{\circ} \mathrm{F}$. Figure 9 illustrates ice tracings from Runs 9 and 10 . In Run 9 , only supercooled liquid water at $0.7 \mathrm{~g} / \mathrm{m}^{3}$ was used. The clear ice accumulation in the stagnation region and the beginning formation of horns away from the stagnation was an indication of glaze ice accretion where the freezing fraction was less than unity. In Run $10,0.7 \mathrm{~g} / \mathrm{m}^{3}$ of frozen ice particles were added to the cloud, producing a TWC of $1.4 \mathrm{~g} / \mathrm{m}^{3}$. Surprisingly, the accreted ice was decreased instead of increased. The ice feathers and "horns" disappeared compared to the previous case. In addition, a slight reduction in accreted ice around the stagnation area is visible from the tracings. This could be caused by a combination of erosion and splashing of the existing liquid layer in that area due to the low freezing fraction. Interestingly, the accreted ice changed from clear to opaque white as in the rime cases with a slight bumpy texture. The explanation could be that impacting ice particles leave residuals that get trapped by the liquid layer. In addition, the smaller ice particles may actually stick to the surface when a liquid layer exists. In rime cases, the supercooled water droplets freeze on impact, leaving a smooth hard surface for ice particles to strike and bounce off, the same as in the case of the fully glaciated icing conditions.

When the surface is heated, significant liquid water is observed on the surface around the stagnation region in the evaporative case and over the entire heated region and beyond in the running-wet case. This was observed whether the icing conditions were due to all liquid supercooled water, mixedphased, or fully glaciated conditions. This indicates that ice will stick, at least partially, to heated surfaces. The videos still showed particles bouncing, but the magnitude could not be quantified with current imaging tools. Splashing is another phenomenon observed that could not be readily quantified.

For each test run, a movie sequence has been created from the available video camera footage and any still photos of the resulting ice accretion.

\subsection{THERMAL TEST RESULTS}

The validity of the thermal data relies on the following: 
- Accuracy of the tunnel simulation capability of the various conditions

- Model design and instrumentation

- TTMS data acquisition and control

The repeatability of the tunnel capabilities in supercooled liquid water conditions has been established over the last several years. Considering that the mixed phase simulation is a new addition to the tunnel simulation capabilities, its accuracy will have to be proven by repeated testing over the next few months or years. However, the following results indicate that the data is meaningful and predictable in relation to the corresponding conditions.

A dry heated test is a very good measure of repeatability of other tunnel conditions (airspeed and temperature), the model instrumentation, and the TTMS data acquisition and control. In most runs, the model was stabilized to evaporative surface temperature conditions. The individual heater powers were measured by the TTMS. The resulting data was used to compute the external heat transfer coefficient for each heater. Results at two ambient conditions are shown in Figures 10 and 11. It is clear that the results are very consistent between all the different runs. The slight nonsymmetry in the results is associated with the hilite heaters (\#4 and \#11) being offset chordwise by as much as 0.1 to 0.18 inch from the hilite. At the aft most heaters (Numbers 1, 7, 8, and 14), an increase in the heat transfer coefficient was noticed. This was due to transition from laminar to turbulent flow.

Due to the large volume of data to be presented, cases for the two different ambient temperatures will be discussed separately. However, It will be shown that the colder conditions were more severe, requiring more power, than the warmer ones for the same cloud conditions.

The total power was computed for all heaters for the following conditions:

1) Evaporative at $0^{\circ} \mathrm{F}$ ambient

2) Evaporative at $12^{\circ} \mathrm{F}$ ambient

3) Running-wet at $0^{\circ} \mathrm{F}$ ambient

4) Running-wet at $12^{\circ} \mathrm{F}$ ambient

\subsubsection{Evaporative Anti-icing}

All the results are presented for a TWC of $0.7 \mathrm{~g} / \mathrm{m}^{3}$ unless otherwise specified. The highest power required of all of the runs was determined to correspond to the case of supercooled liquid water only, at $0^{\circ} \mathrm{F}$ ambient temperatures, and in the fully evaporative case. Consequently, all the powers from the different runs were normalized to that value. Figure 12 illustrates the normalized total powers at $0^{\circ} \mathrm{F}$ ambient temperature.

In the following discussions and figures, "Spray Bars" indicates only supercooled liquid water, "MixGun" and "MixShaver" indicates a mixed-phase condition with $50 \%$ water content, and "Shaver" or "Gun" indicates fully glaciated icing conditions. The dry condition data is shown for reference. The spanwise and chordwise symmetric data have been averaged so that the results for seven heaters only are presented.

The general trend observed suggests that the maximum power in a decreasing order for the evaporative cases is as follows:

1) All supercooled water droplets

2) Mixed-phase icing conditions

3) Fully glaciated icing conditions

Looking at the actual distribution of these powers sheds more light on the effects of ice particles in the cloud. Figure 13 illustrates the distributions corresponding to evaporative powers at $0^{\circ} \mathrm{F}$. The case labeled "Gun low LWC" corresponds to ice crystals only at $0.35 \mathrm{~g} / \mathrm{m}^{3}$. The results showed a reduction of power required for that case. There are two interesting phenomena to observe:

1) Power on the edge heaters, specifically \#2 and \#6, are reduced in the case of mixed or glaciated conditions. This could be another indication for erosion.

2) The power required on the hilite, heater \#4, is near $31 \mathrm{~W} / \mathrm{in}^{2}$. This corresponds to the maximum heater design power. In those cases, the hilite heater ran below the specified surface temperature of $150^{\circ} \mathrm{F}$.

Similarly, the results corresponding to evaporative conditions at $12^{\circ} \mathrm{F}$ ambient temperature are shown in Figures 14 and 15. The trend observed here is identical to the colder case. But the respective normalized powers are slightly lower due to the decrease in the convective and evaporative losses. However, the erosion effects are more visible in Figure 15 in the heated regions just downstream of the hilite than in the corresponding Figure 13 for the $0^{\circ} \mathrm{F}$ case.

\subsubsection{Running-wet Anti-icing}

Now consider the running-wet anti-icing cases. Figure 16 illustrates the normalized total powers at $0^{\circ} \mathrm{F}$ ambient temperature. Clearly, the total required power is much less than in the evaporative cases. The trend shown here indicates that the power required in decreasing order corresponds to the 
mixed phases, followed by the fully glaciated and supercooled droplets clouds.

Detailed inspection of the actual power distributions shown in Figure 17 indicates that for most runningwet cases the power on the hilite is also the maximum available, as in the evaporative cases. Notably, the heaters just downstream of the hilite required very little heat in mixed and glaciated conditions. There are two possible reasons for that:

1) The ice accumulation on the hilite required high power as a result of the additional heat of fusion required to melt the ice crystals. Some of the heat generated on the hilite conducts in the chordwise direction to adjacent heaters.

2) The erosion effects observed on the unheated model in glaze ice conditions could have played a role here. The liquid runback water downstream of the hilite may have been removed from the surface by the solid particles, which strike those regions and bounce off the surface producing a "sand blasting" effect as presented in the ice tracing earlier.

Finally, the results corresponding to running-wet cases at $12^{\circ} \mathrm{F}$ ambient temperature are shown in Figures 18 and 19 . The trend observed here is similar to that of the $0^{\circ} \mathrm{F}$ case as far as the power distributions and erosion effects. Generally, the powers in this warm case are small compared to the evaporative cases.

\subsection{CONCLUDING REMARKS}

A new capability to simulate glaciated and mixedphase icing conditions was developed and demonstrated in the Cox IWT. An experimental program, sponsored by the FAA, was conducted to quantify the effects of mixed-phase and glaciated icing conditions on the power requirements of thermal ice protection systems. The investigation was limited to a lifting surface at zero degree angle of attack.

Visualization techniques and test methods were developed and demonstrated during this test process. Erosion effects were evident, especially in glaze icing conditions. Resulting accretions were usually smoothed and tended to be opaque white as is common in rime cases. Erosion effects were documented through ice tracings, visual data, as well as thermal data.

Evaporative thermal systems on lifting surfaces are not adversely affected by the state of the water content, but rather by its total content in the atmosphere. In fact, the total power requirements may be reduced in mixed-phase conditions as a result of the observed erosion effects.

Running-wet thermal systems on lifting surfaces can be overwhelmed at the stagnation region by high ice contents when insufficiently heated, but the overall power requirements are still insignificant compared to evaporative cases. Consequently, if a system is designed to operate at or near evaporative power levels, it should function satisfactorily in mixedphase conditions. In running-wet operations, the power requirements were generally highest in mixed icing conditions compared to fully glaciated or supercooled liquid only cloud conditions.

The test methodologies and imaging tools developed in this program can be transferred to an aircraft test bed for flight studies in natural icing conditions. However, extensive data should be collected to be conclusive. An actual flight test program might prove very difficult due to the high fluctuations in ambient conditions.

Other applications for mixed phase testing in the tunnel include the investigation of heated instrumentation and air data probes. Also, if the ice shaver is used, higher speed effects and better close-up imaging can be conducted in TS-1 of the Cox IWT since current data is limited to a speed of $120 \mathrm{mph}$.

The studies were conducted with currently available simulation methods and visualization techniques. Although the ice particles simulated here may represent only a small percentage of the types that may exist in nature and direct correlations to nature may not be possible, the trends observed are expected to be valid. This is especially true in the case of heated surfaces.

\subsection{REFERENCES}

1. JAR Requirements - Mixed Phase Icing: JAR 25.1419 and ACJ 25.1419.

2. Certification of Transport Category Rotorcraft, Federal Aviation Administration, Advisory Circular 29-2C.

3. Isaac, G.A., Cober, S.G., Korolev, A.V., Strapp, J.W. and Tremblay, A., "Canadian freezing Drizzle Experiment," AIAA $37^{\text {th }}$ Aerospace Sciences Meeting and Exhibit, Reno, NV, Jan 1999, AIAA Paper 99-0492.

4. Cober, S.G., Isaac, G.A., Korolev, A.V., Strapp, J.W., and Marcotte, D.L., "Measurements of aircraft icing environments which include supercooled large drops," AIAA $37^{\text {th }}$ Aerospace 
Sciences Meeting and Exhibit, Reno, NV, Jan 1999, AIAA Paper 99-0494.

5. Isaac, G.A., Cober, S.G., Strapp, J.W., Hudak, D., Ratvasky, T.P., Marcotte, D.L., and Fabry, F., "Preliminary results from the Alliance Icing Research Study (AIRS)," AIAA $39^{\text {th }}$ Aerospace Sciences Meeting and Exhibit, Reno, NV, Jan 2001, AIAA Paper 2001-0393.

6. Cober, S.G., Ratvasky, T.P., and Isaac, G.A., "Assessment of aircraft icing conditions observed during AIRS," AIAA $40^{\text {th }}$ Aerospace Sciences Meeting \& Exhibit, Reno, NV, Jan 2002, AIAA Paper 2002-0674.

7. Cober, S.G., and Isaac, G.A., "Aircraft icing environments observed in mixed-phase clouds," AIAA 40 ${ }^{\text {th }}$ Aerospace Sciences Meeting \& Exhibit, Reno, NV, Jan 2002, AIAA Paper 20020675.

8. Hallett, J., and Isaac, G.A., "Aircraft icing in glaciated and mixed phase clouds," AIAA $40^{\text {th }}$ Aerospace Sciences Meeting \& Exhibit, Reno, NV, Jan 2002, AIAA Paper 2002-0677.

9. Korolev, A.V., Isaac, G.A., Strapp, J.W., and Cober, S.G., "Observation of drizzle at temperatures below $-20^{\circ} \mathrm{C}$," AIAA $40^{\text {th }}$ Aerospace Sciences Meeting \& Exhibit, Reno, NV, Jan 2002, AIAA Paper 2002-0678.

10. Miller, D., Ratvasky, T., Ranaudo, R., Bernstein, B., "NASA/NCAR/FAA Supercooled Large Droplet Icing Flight Research: Summary of Winter 96-97 Flight Operations," AIAA $36^{\text {th }}$ Aerospace Sciences Meeting, Reno, NV, Jan 1998, AIAA Paper 98-0577.

11. "FAA Inflight Aircraft Icing Plan", US DOT, Federal Aviation Administration, April 1997.
12. Al-Khalil, K.M., "Effect of Mixed Icing Conditions on Thermal Ice Protection Systems," FAA Specialists' Workshop on Mixed-Phase and Glaciated Icing Conditions, Atlantic City NJ, Dec. 2-3, 1998.

13. Riley, J.T., "Mixed Phase Icing Conditions: A Review," FAA Specialists' Workshop on Mixed Phase and Glaciated Icing Conditions, Atlantic City, NJ, Dec. 2-3, 1998.

14. Miller, D.R., Wright, W.B., and Al-Khalil, K.M., "Validation of Thermal Ice Protection Computer Codes: Part 1- Program Overview," AIAA $35^{\text {th }}$ Aerospace Sciences Meeting, Reno, NV, Jan 1997, AIAA Paper 97-0049.

15. Wright, W.B., Miller, D.R., and Al-Khalil, K.M., "Validation of Thermal Ice Protection Computer Codes: Part 2- The Validation of LEWICE / Thermal," AIAA 35 ${ }^{\text {th }}$ Aerospace Sciences Meeting, Reno, NV, Jan 1997, AIAA Paper 97-0050.

16. Al-Khalil, K.M., Horvath, C., Miller, D.R., and Wright, W.B., "Validation of Thermal Ice Protection Computer Codes: Part 3- The Validation of ANTICE," AIAA $35^{\text {th }}$ Aerospace Sciences Meeting, Reno, NV, Jan 1997, AIAA Paper 97-0051. 


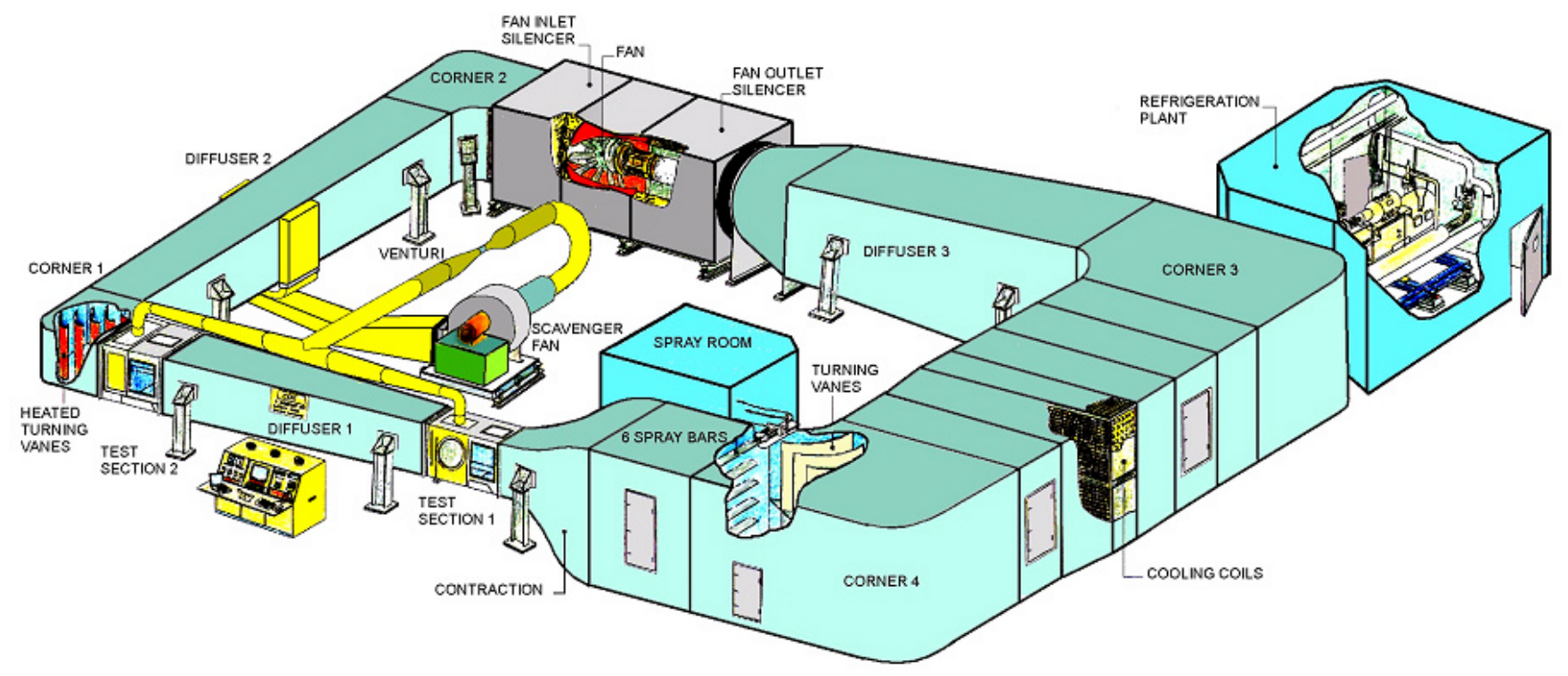

Figure 1: Layout of the IWT at the Cox LeClerc Icing Research Laboratory

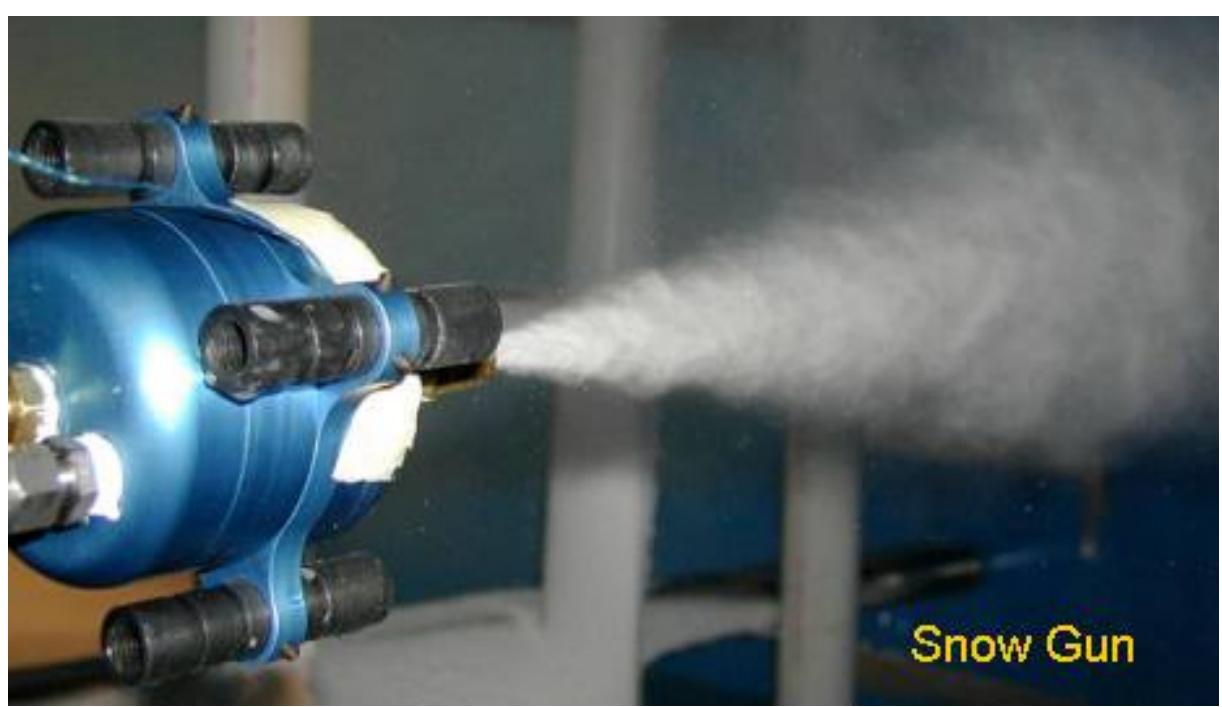

Figure 2: Snow gun in the Cox IWT

\section{Snowgun}
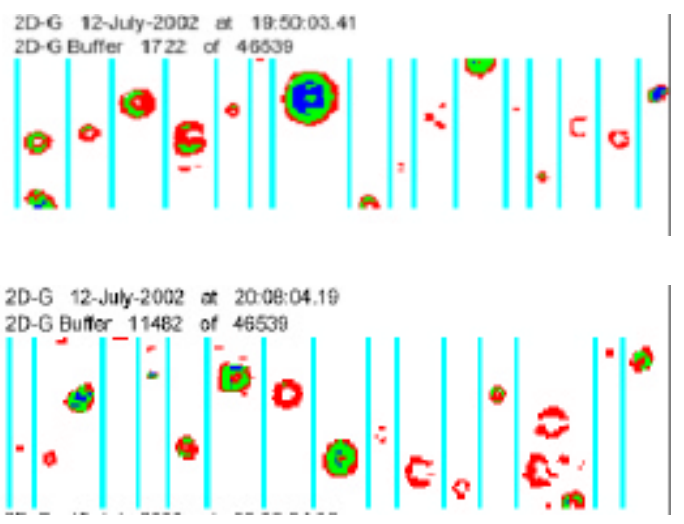

Shaved Ice

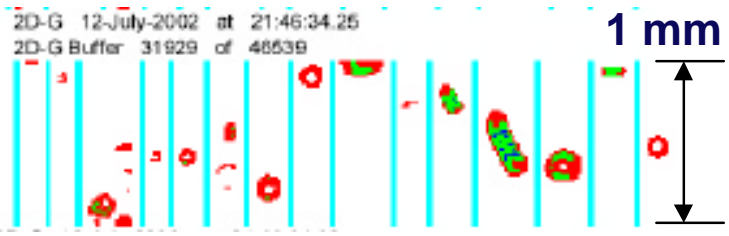

2D-G 12 Juy 2002 at 215353.46 $20-6$ Bufler 35735 of 46539

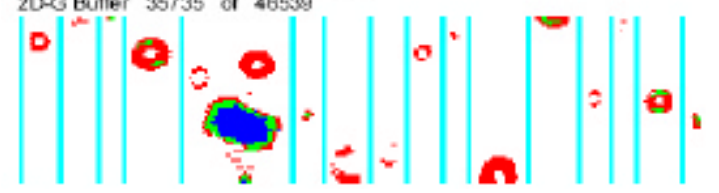

Figure 3: Ice Particle imaging using the OAP-2Dgrey probe 


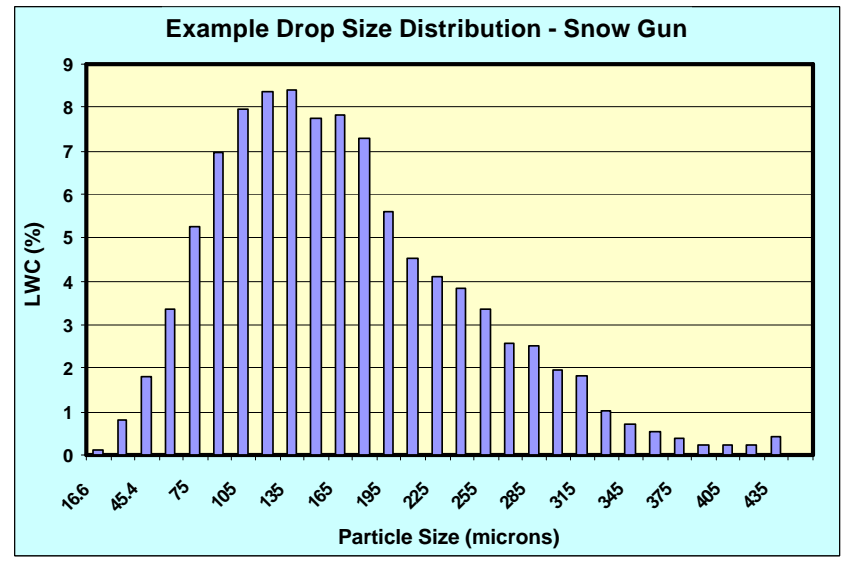

Figure 4: Sample snow gun particle distribution

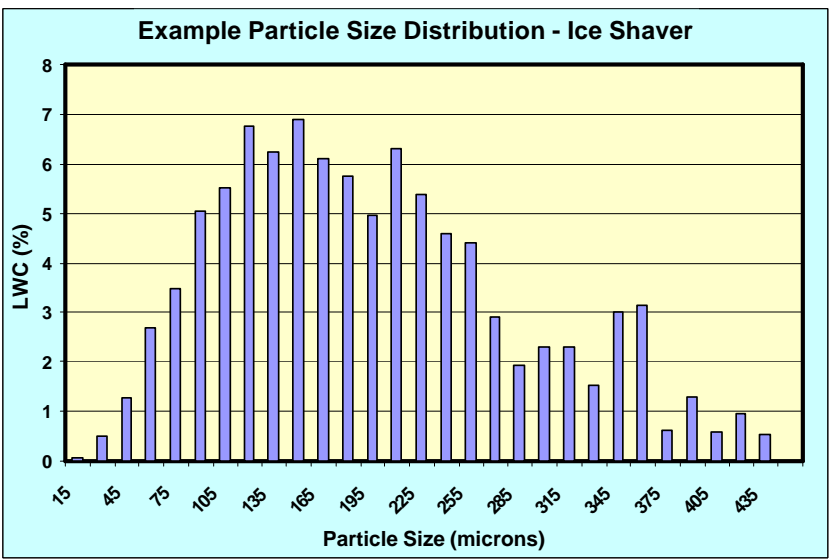

Figure 5: Sample ice shaver particle distribution

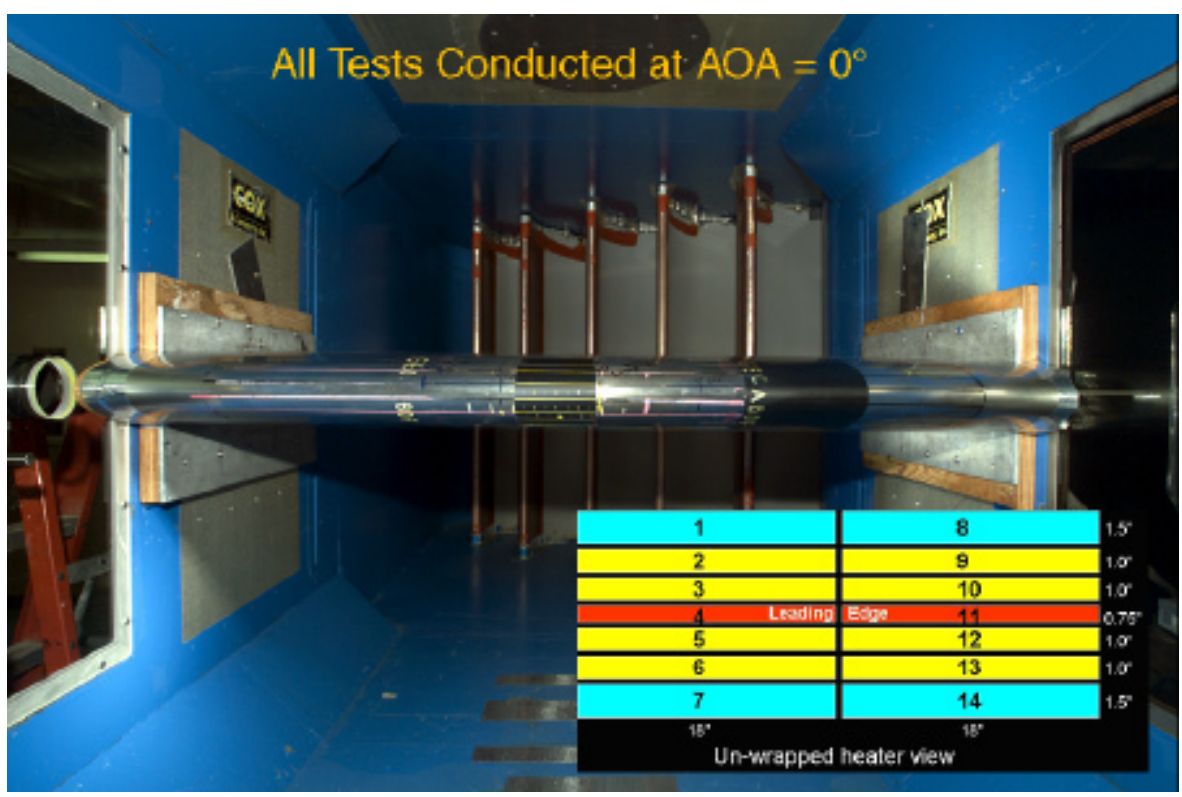

Figure 6: NACA0012 Model (36" chord) Installed in TS-2

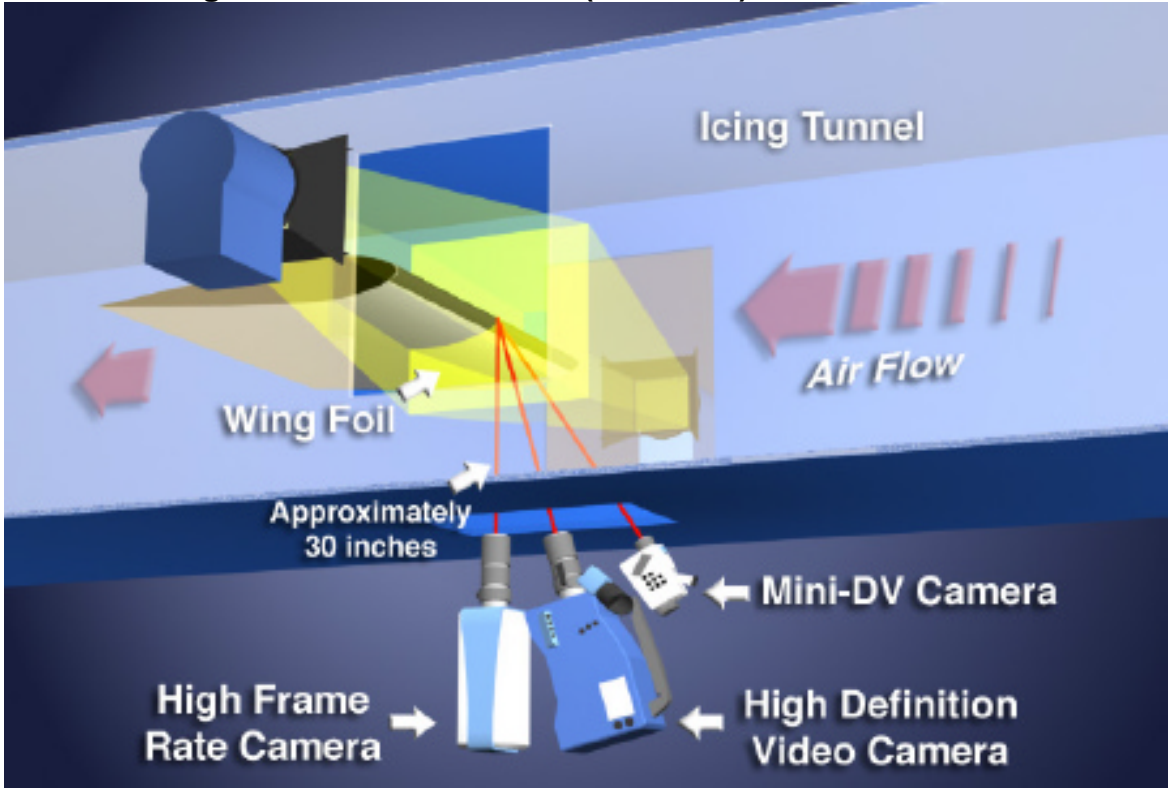

Figure 7: Video Imaging Setup 
Table 1: Icing Test Conditions

\begin{tabular}{|c|c|c|c|c|c|c|}
\hline $\begin{array}{c}\text { Icing } \\
\text { Test } \\
\text { Condition } \\
\end{array}$ & $\begin{array}{c}\text { True } \\
\text { AirSpeed } \\
\text { (mph) } \\
\end{array}$ & $\begin{array}{c}\text { Total } \\
\text { Temp. } \\
\left({ }^{\circ} \mathrm{F}\right) \\
\end{array}$ & $\begin{array}{c}\text { Spraybar * } \\
\text { LWC } \\
\left(\mathrm{g} / \mathrm{m}^{3}\right) \\
\end{array}$ & $\begin{array}{c}\text { Snow Gun } \\
I W C \\
\left(\mathrm{~g} / \mathrm{m}^{3}\right)\end{array}$ & $\begin{array}{c}\text { Ice Shaver } \\
\text { IWC } \\
\left(\mathrm{g} / \mathrm{m}^{3}\right)\end{array}$ & $\begin{array}{c}\text { TWC } \\
\left(\mathrm{g} / \mathrm{m}^{3}\right) \\
\end{array}$ \\
\hline \multicolumn{7}{|l|}{ WARM } \\
\hline 1 & 120 & 12 & 0.70 & & & 0.70 \\
\hline 2 & 120 & 12 & 0.35 & 0.35 & & 0.70 \\
\hline 3 & 120 & 12 & 0.30 & 0.70 & & 1.00 \\
\hline 4 & 120 & 12 & 0.70 & 0.30 & & 1.00 \\
\hline 5 & 120 & 12 & 0.35 & & 0.35 & 0.70 \\
\hline 6 & 120 & 12 & & & 0.70 & 0.70 \\
\hline 7 & 120 & 12 & & 0.70 & & 0.70 \\
\hline \multicolumn{7}{|l|}{ COLD } \\
\hline 8 & 120 & 0 & 0.70 & & & 0.70 \\
\hline 9 & 120 & 0 & 0.35 & 0.35 & & 0.70 \\
\hline 10 & 120 & 0 & 0.35 & & 0.35 & 0.70 \\
\hline 11 & 120 & 0 & & & 0.70 & 0.70 \\
\hline 12 & 120 & 0 & & 0.70 & & 0.70 \\
\hline 13 & 120 & 0 & & 0.30 & & 0.30 \\
\hline \multicolumn{7}{|c|}{ WARMEST (TRACINGS ONLY) } \\
\hline 14 & 120 & 22 & 0.70 & & & 0.70 \\
\hline 15 & 120 & 22 & 0.70 & & 0.70 & 1.40 \\
\hline
\end{tabular}

Table 2: Matrix of lcing Test Runs

\begin{tabular}{|c|c|c|c|c|c|}
\hline $\begin{array}{c}\text { Tunnel } \\
\text { Run } \\
\text { No. }\end{array}$ & $\begin{array}{c}\text { Icing } \\
\text { Test } \\
\text { Condition }\end{array}$ & \begin{tabular}{|c|} 
IPS \\
Thermal \\
Condition
\end{tabular} & $\begin{array}{c}\text { Tunnel } \\
\text { Run } \\
\text { No. }\end{array}$ & \begin{tabular}{|c|} 
Icing \\
Test \\
Condition
\end{tabular} & $\begin{array}{c}\text { IPS } \\
\text { Thermal } \\
\text { Condition }\end{array}$ \\
\hline $7 / 16 / 2002$ & & & $7 / 18 / 2002$ & (continued) & \\
\hline 1 & 6 & Off & 24 & \begin{tabular}{|l|}
9 \\
\end{tabular} & Off \\
\hline 2 & 6 & Off & 25 & 8 & Evap \\
\hline 3 & 5 & Off & 26 & 8 & Run-wet \\
\hline 4 & 5 & Off & 27 & 11 & Evap \\
\hline 5 & 1 & Off & 28 & 11 & Run-wet \\
\hline 6 & 11 & Off & $7 / 19 / 2002$ & & \\
\hline 7 & 10 & Off & 29 & 2 & Evap \\
\hline 8 & 8 & Off & 30 & 2 & Run-wet \\
\hline $7 / 17 / 2002$ & & & 31 & 7 & Evap \\
\hline 9 & 14 & Off & 32 & 7 & Run-wet \\
\hline 10 & 15 & Off & 33 & 9 & Evap \\
\hline 11 & 1 & Evap & 34 & 9 & Run-wet \\
\hline 12 & 1 & Run-wet & 35 & 12 & Evap \\
\hline 13 & 5 & Evap & 36 & 12 & Run-wet \\
\hline 14 & 5 & Run-wet & 37 & 10 & Evap \\
\hline 15 & 6 & Evap & 38 & 10 & Run-wet \\
\hline 16 & 6 & Run-wet & 39 & 10 & Off \\
\hline 17 & 6 & Run-wet & 40 & 13 & Evap \\
\hline $7 / 18 / 2002$ & & & $7 / 23 / 2002$ & & \\
\hline 18 & 2 & Off & 41 & 12 & Evap \\
\hline 19 & 3 & Off & 42 & 12 & Run-wet \\
\hline 20 & 4 & Off & 43 & 9 & Off \\
\hline 21 & 7 & Off & 46 & 12 & Evap \\
\hline 22 & 13 & Off & 44 & 11 & Evap \\
\hline 23 & 12 & Off & 45 & 11 & Run-wet \\
\hline
\end{tabular}




\section{Rime Icing Condition}

Cox \& Company, Inc.

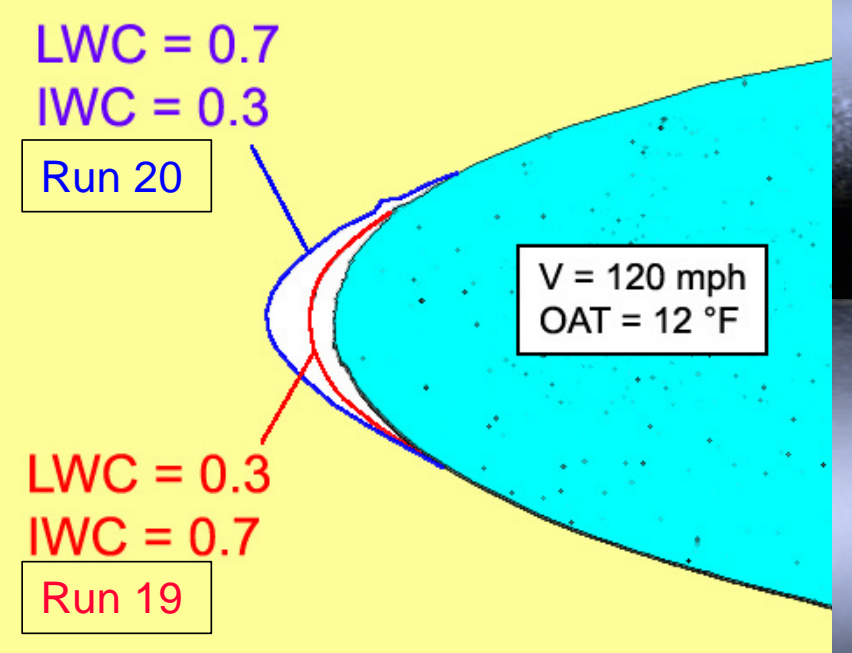

Run 20

Run 19

Figure 8: Erosion effects on ice accretions in rime conditions

\section{Glaze Icing Condition}

Cox \& Company, Inc.

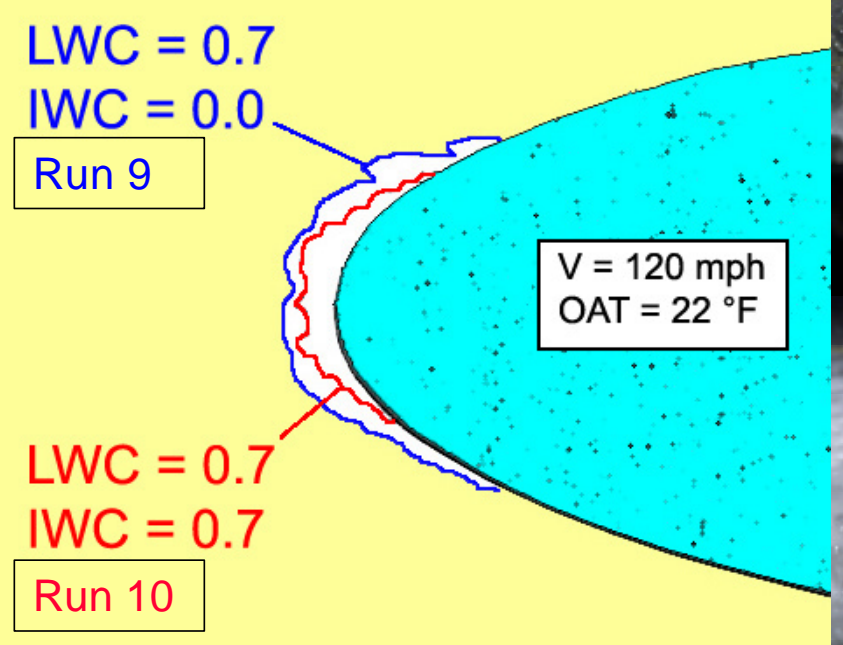

Run 10

Figure 9: Erosion effects on ice accretions in glaze conditions 


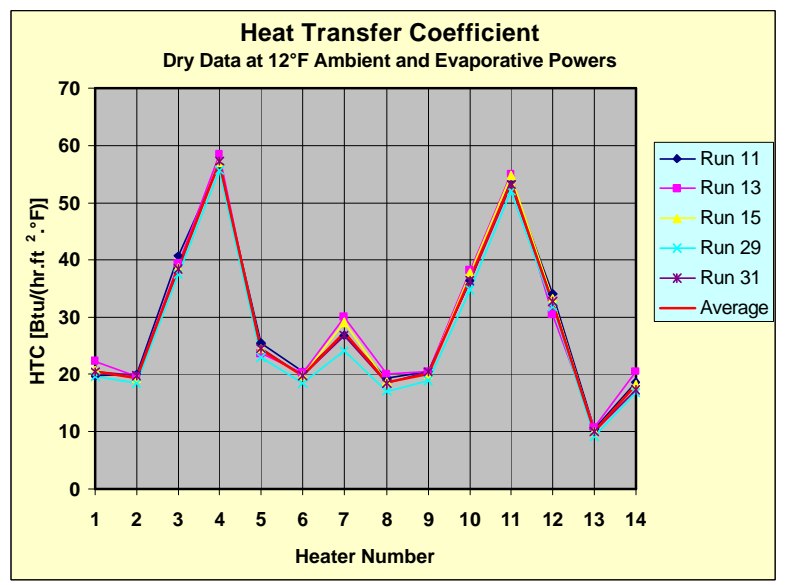

Figure 10: Tunnel Sample Dry Data at $12{ }^{\circ} \mathrm{F}$

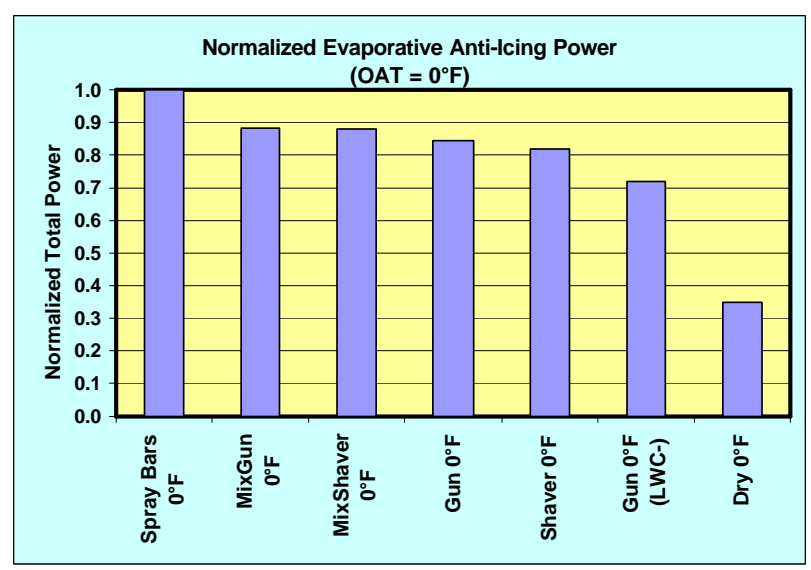

Figure 12: Summary of Normalized Evaporative Total Power at $0^{\circ} \mathrm{F}$

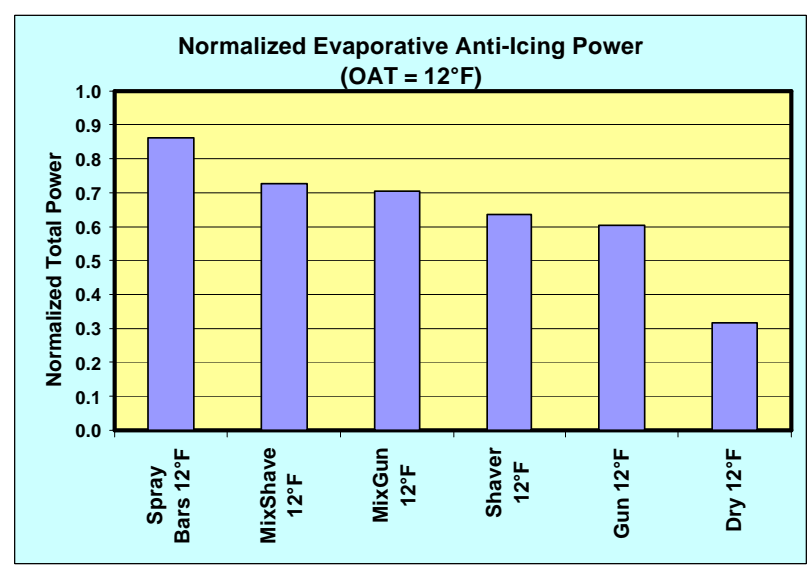

Figure 14: Summary of Normalized Evaporative Total Power at $12^{\circ} \mathrm{F}$

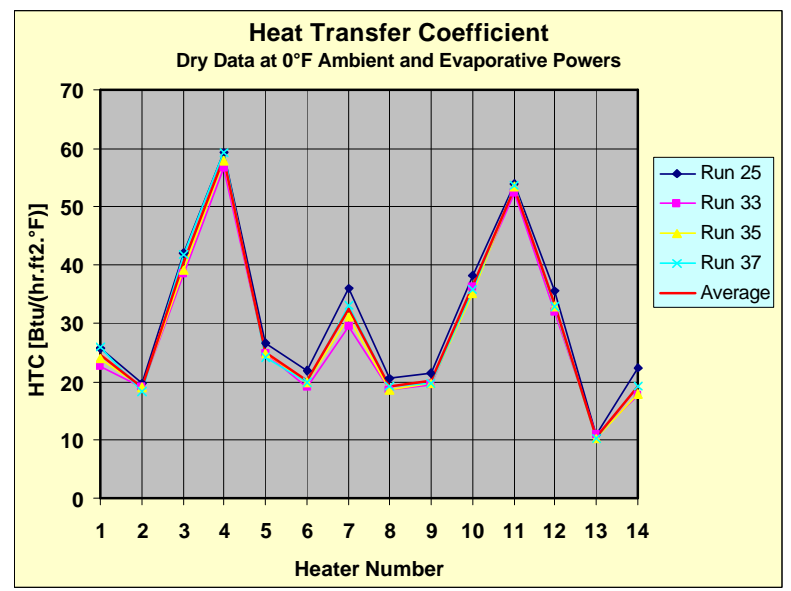

Figure 11: Tunnel Sample Dry Data at $0{ }^{\circ} \mathrm{F}$

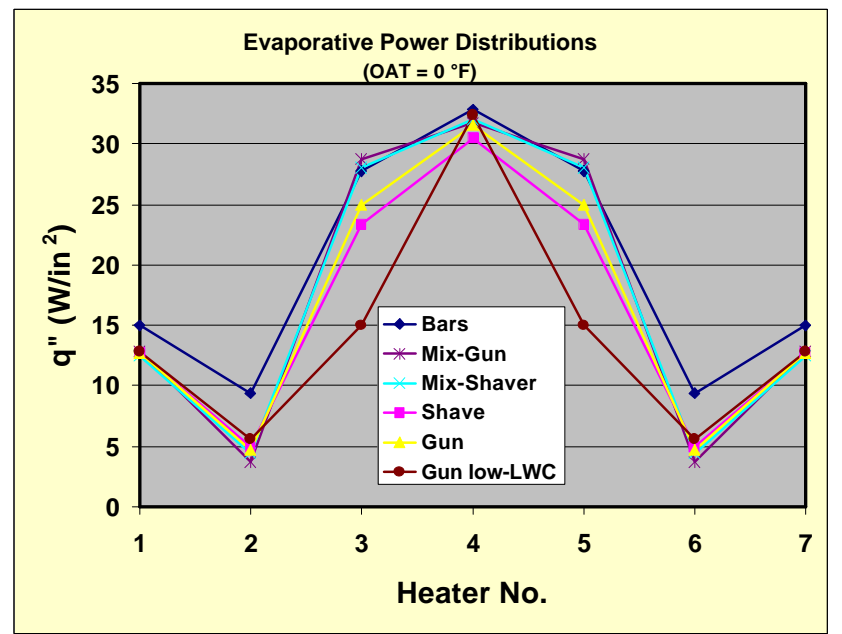

Figure 13: Evaporative Power Distributions at $0^{\circ} \mathrm{F}$

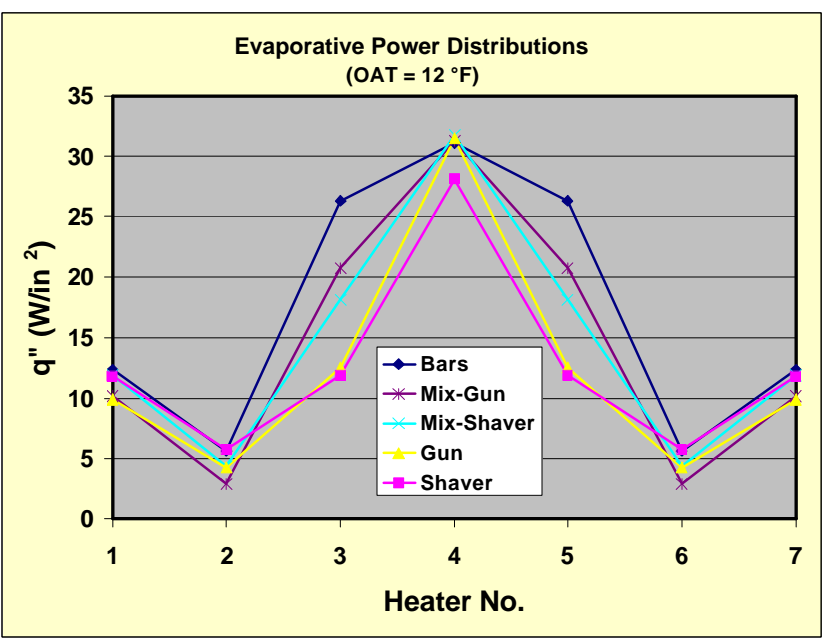

Figure 15: Evaporative Power Distributions at $12^{\circ} \mathrm{F}$ 


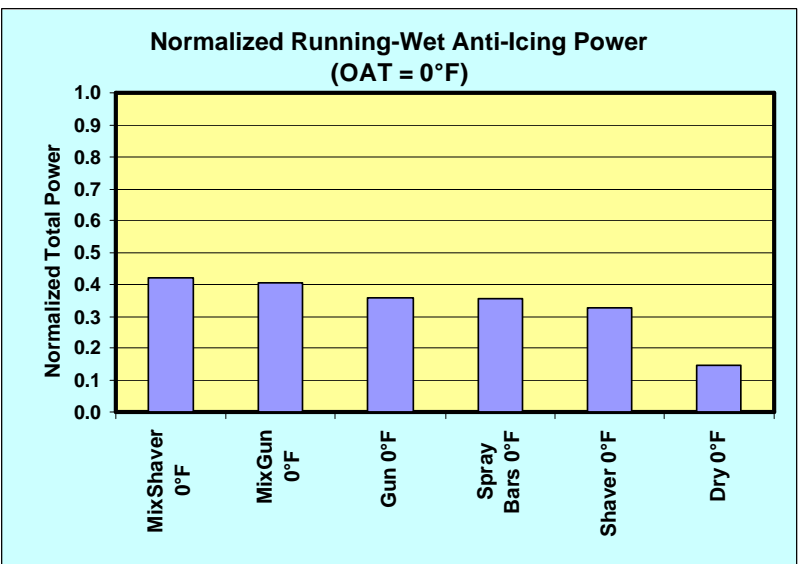

Figure 16: Summary of Normalized Running-Wet Total power at $0^{\circ} \mathrm{F}$

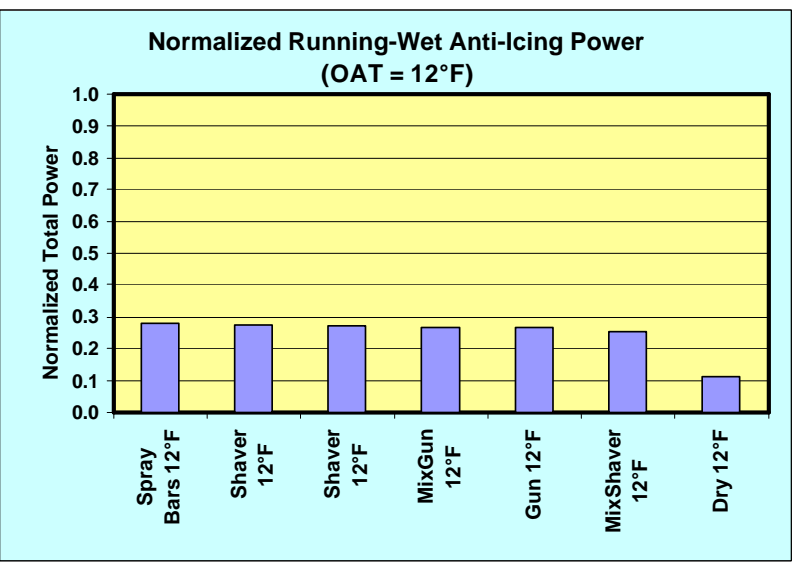

Figure 18: Summary of Normalized Running-Wet Total power at $12^{\circ} \mathrm{F}$

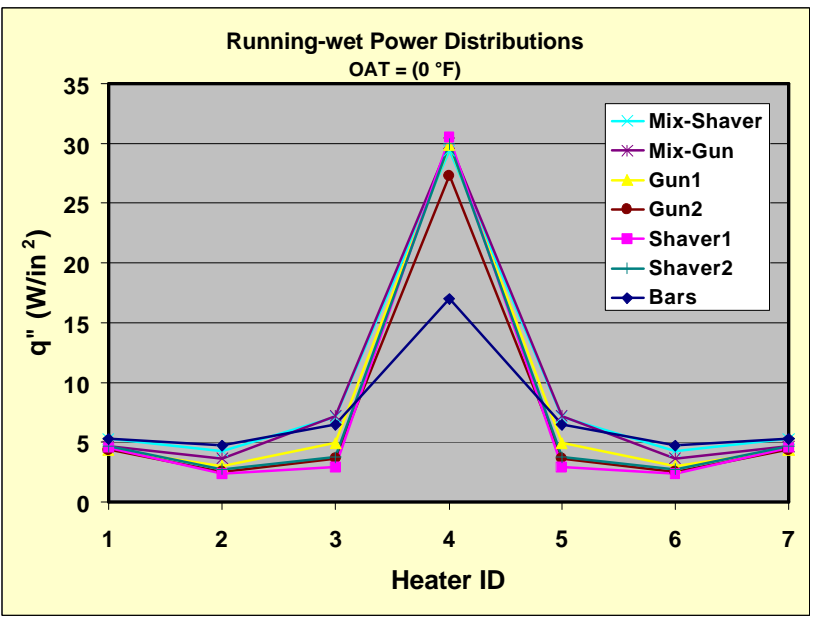

Figure 17: Running-Wet Power Distributions at $0^{\circ} \mathrm{F}$

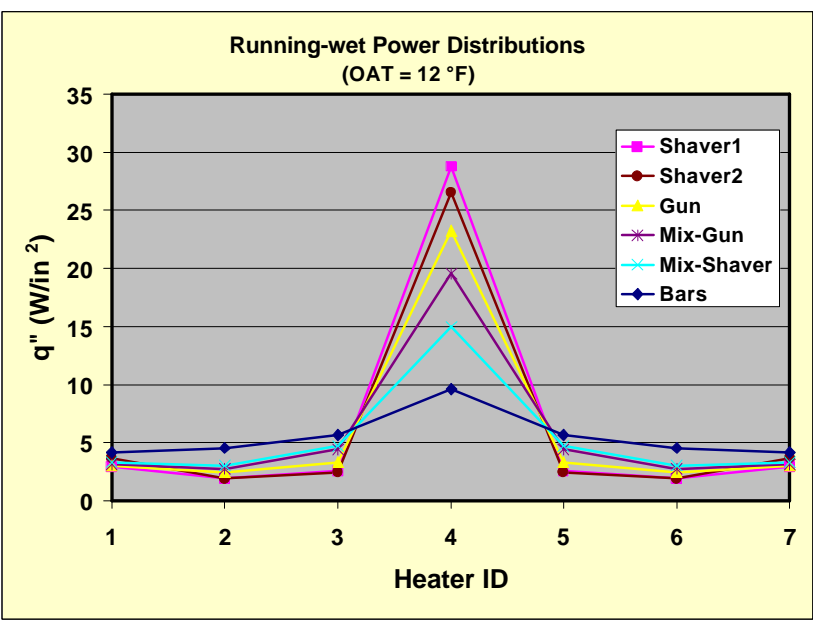

Figure 19: Running-Wet Power Distributions at $12^{\circ} \mathrm{F}$

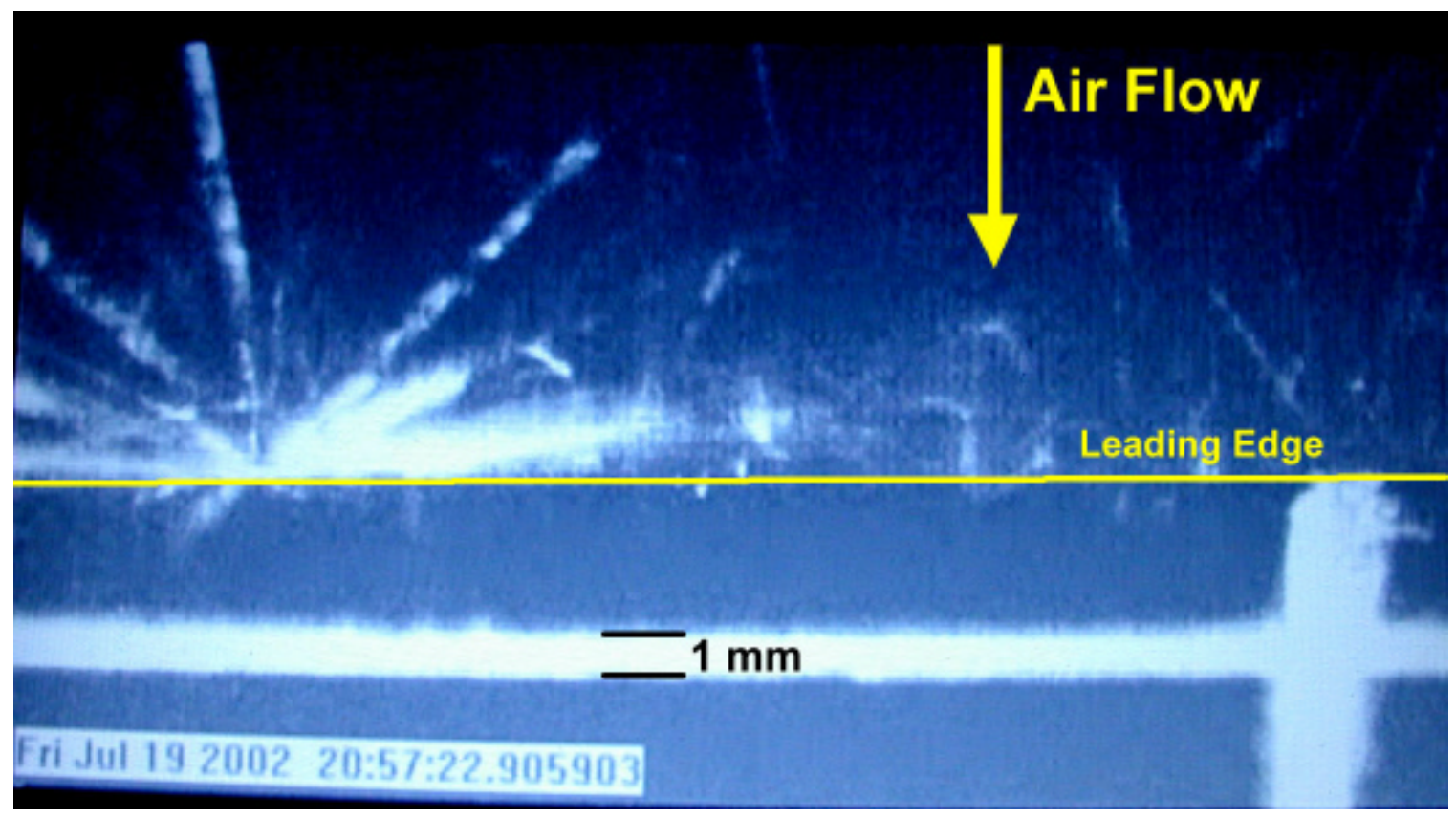

Figure 20: Ice Particle Impact/Bounce captured during Run 37 


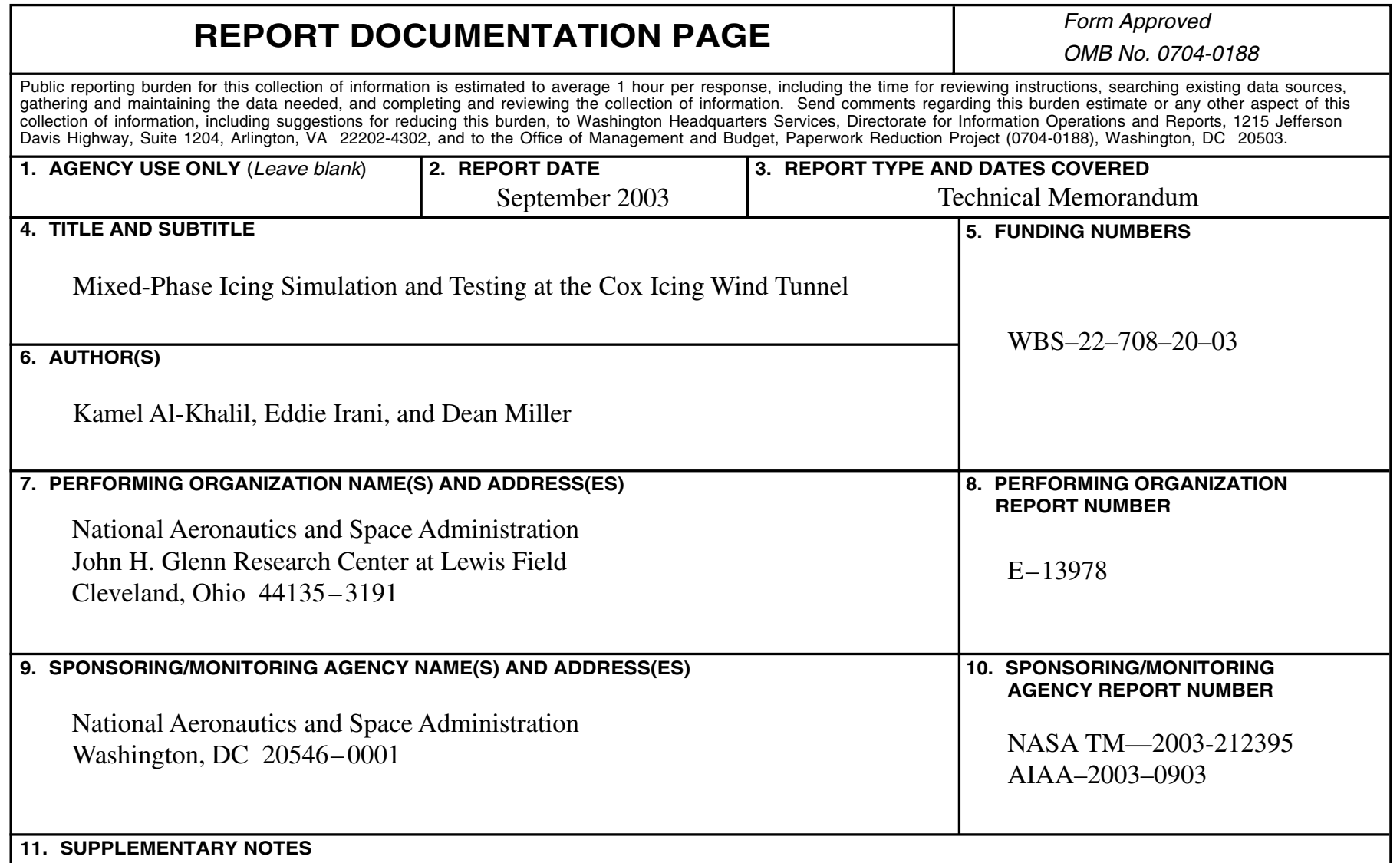

Prepared for the 41st Aerospace Sciences Meeting and Exhibit sponsored by the American Institute of Aeronautics and Astronautics, Reno, Nevada, January 6-9, 2003. Kamel Al-Khalil and Eddie Irani, Cox \& Company, Inc., New York, New York 10014; Dean Miller, NASA Glenn Research Center. Responsible person, Dean Miller, organization code 5840, 216-433-5349.

12a. DISTRIBUTION/AVAILABILITY STATEMENT 12b. DISTRIBUTION CODE

Unclassified - Unlimited

Subject Categories: 03 and 34

Distribution: Nonstandard

Available electronically at http://gltrs.grc.nasa.gov

This publication is available from the NASA Center for AeroSpace Information, 301-621-0390.

\section{ABSTRACT (Maximum 200 words)}

A new capability was developed for indoor simulation of snow and mixed-phase icing conditions. This capability is useful for year-round testing in the Cox closed-loop Icing Wind Tunnel. Certification of aircraft for flight into these types of icing conditions is only required by the JAA in Europe. In an effort to harmonize certification requirements, the FAA in the U.S. sponsored a preliminary program to study the effects of mixed-phase and fully glaciated icing conditions on the performance requirements of thermal ice protection systems. This paper describes the test program and the associated results.

\begin{tabular}{|c|c|c|}
\hline \multicolumn{3}{|c|}{$\begin{array}{l}\text { 14. SUBJECT TERMS } \\
\text { Supercooled large droplets (SLD) icing conditions; ATR-72 accident; Mixed-phase; } \\
\text { Glaciated icing conditions; Alliance icing research study (AIRS); Canadian freezing } \\
\text { drizzle experiment (CFDE) }\end{array}$} \\
\hline $\begin{array}{l}\text { 17. SECURITY CLASSIFICATION } \\
\text { OF REPORT }\end{array}$ & $\begin{array}{l}\text { 18. SECURITY CLASSIFICATION } \\
\text { OF THIS PAGE }\end{array}$ & $\begin{array}{l}\text { 19. SECURITY CLASSIFICATION } \\
\text { OF ABSTRACT }\end{array}$ \\
\hline Unclassified & Unclassified & Unclassified \\
\hline
\end{tabular}

NSN 7540-01-280-5500 15. NUMBER OF PAGES 19 